\title{
THE SECURITY COUNCIL, THE INTERNATIONAL CRIMINAL COURT, AND THE CRIME OF AGGRESSION: HOW EXCLUSIVE IS THE SECURITY COUNCIL'S POWER TO DETERMINE AGGRESSION?
}

\author{
Mark S. Stein*
}

\section{INTRODUCTION}

One of the most contentious issues surrounding the new International Criminal Court (ICC) is what role the Security Council should play in prosecuting the crime of aggression. In the negotiations that led to the adoption of the Rome Statute of the International Criminal Court, ${ }^{1}$ the participants could not agree on the Security Council's role, and they also could not agree on how to define the crime of aggression. Accordingly, these issues were postponed. Article 5(2) of the ICC Statute states that the ICC "shall exercise jurisdiction over the crime of aggression once a provision is adopted in accordance with articles 121 and 123 defining the crime and setting out the conditions under which the Court shall exercise jurisdiction with respect to this crime."2 Such an amendment, Article 5(2) directs, "shall be consistent with the relevant provisions of the Charter of the United Nations."

Some contend that under the U.N. Charter, the Security Council must determine the existence of an act of aggression as a precondition to any prosecution for the crime of aggression. ${ }^{4}$ They point to Article 39 of the U.N. Charter, which states: "The Security Council shall determine the existence of

*Adjunct Assistant Professor, University of Missouri-St. Louis, Dept. of Political Science. Ph.D. 2001, Yale University; J.D., 1983, University of Michigan. Financial support for this article was provided by the Lentz Peace Research Association and the University of Missouri-St. Louis. I acknowledge with thanks the comments of Don Ferencz and Leila Nadya Sadat. Mistakes are my own.

1. Rome Statute of the International Criminal Court, July 17, 1998, U.N. Doc. A/CONF.183/9 (1998), corrected through Jan. 16, 2002, available at

www.icc-cpi.int/library/about/officialjournal/Rome_Statute_120704-EN.pdf (last visited Sept. 26,2005 ) [hereinafter ICC Statute].

2. Id. at art. 5(2).

3. Id.

4. This was the view of the International Law Commission. Report of the International Law Commission on the Work of its Forty-Sixth Session, Draft Statute for an International Criminal Court, U.N. GAUR, $49^{\text {th }}$ Sess., Supp. No. 10 at 86 , U.N. Doc. A/49/10 (1994) [hereinafter ILC Draft Statute] ("Any criminal responsibility of an individual for an act or crime of aggression necessarily presupposes that a State had been held to have committed aggression, and such a finding would be for the Security Council acting in accordance with Chapter VII of the Charter to make.") For similar views, see Matthias Schuster, The Rome Statute and the Crime of Aggression: A Gordian Knot in Search of a Sword, 14 Criminal Law Forum 1, 35-39 (2003); Theodor Meron, Defining Aggression for the International Criminal Court, 25 SUFPOLK TRANSNAT'L L. Rev. 1, 13-14 (2001). 
any threat to the peace, breach of the peace, or act of aggression and shall make recommendations, or decide what measures shall be taken in accordance with Articles 41 and 42 , to maintain or restore international peace and security." Others believe that in the context of an ICC case, the Security Council's power to determine the existence of aggression is not exclusive; they believe that in the ICC context, the Charter permits other bodies, such as the ICC, the International Court of Justice (ICJ), or the General Assembly, to determine the existence of aggression. $^{6}$

The Preparatory Commission of the ICC attempted, unsuccessfully, to resolve issues over the crime of aggression before the entry into force of the ICC Statute in $2002 .^{7}$ Negotiations continue in the Special Working Group on the Crime of Aggression of the Assembly of States Parties to the ICC Statute. Under Article 121 of the ICC Statute, the Statute can be amended to deal with the crime of aggression, at the earliest, seven years after its entry into force (i.e., 2009). ${ }^{8}$ Article 123 of the ICC Statute provides for a Review Conference seven years after the treaty's entry into force "to consider any amendments to this Statute."9

While the ICC is not currently exercising jurisdiction over the crime of aggression, it is exercising jurisdiction over war crimes, crimes against humanity, and the crime of genocide. As to these crimes, the ICC Statute already grants the Security Council considerable power over ICC proceedings. Under ICC Article 16 , the Security Council can suspend an ICC proceeding for a period of twelve months, and such suspensions can be renewed indefinitely. ${ }^{10}$ Under ICC Article 13, the Security Council can refer a case to the ICC, enabling the ICC to exercise jurisdiction over a conflict even if no state involved in that conflict has accepted the ICC's jurisdiction. ${ }^{11}$

Many believe that the Security Council's already-considerable powers under the ICC Statute should be even greater in the context of the crime of aggression. $^{12}$ I share this view. Nevertheless, I argue in this Article that the

5. U.N. ChARTER, art. 39 (emphasis added).

6. Andreas L. Paulus, Peace through Justice? The Future of the Crime of Aggression in a Time of Crisis, 50 WAYNE L. REv. 1, 21-22 (2004). See also the contributions by Giorgio Gaja, Saeid Mirzaee Yengejeh, Paula Escarameia, Marja Lehto, and Luigi Condorelli, in THE INTERNATIONAL. CRIMINAL COURT AND THE CRIME OF AGGRESSION 121-163 (Mauro Politi and Giuseppe Nesi eds., 2004)(all essentially rejecting the exclusivity of the Security Council's Article 39 power).

7. For an overview of discussions at the PrepComm stage, see Silvia A. Fernandez de Gurmendi, Completing the Work of the Preparatory Commission: The Working Group on Aggression at the Preparatory Commission for the International Criminal Court, 25 FORDHAM INT'L L.J. 589 (2002); Roger S. Clark, Rethinking Aggression as a Crime and Formulating its Elements: The Final Work-Product of the Preparatory Commission for the International Criminal Court, 15 LEIDEN J. INT'L L. 859 (2002).

8. ICC Statute, supra note 1, at art. 121.

9. Id. at art. 123.

10. Id. at art. 16.

11. Id. at art. 13(b).

12. For a description of views, see Gurmendi, supra note 7, at 603. 
U.N. Charter permits ICC prosecutions for the crime of aggression where the Security Council has not previously determined the existence of an act of aggression. Indeed, I argue, schemes in which a Security Council determination of aggression is not a precondition are more consistent with the Charter than schemes in which a Security Council determination is a precondition.

Proposals for the involvement of the Security Council in prosecutions for the crime of aggression can be categorized in various ways. ${ }^{13}$ For my purposes, a four-fold categorization is useful. First, there are schemes in which a Security Council determination of aggression is a precondition to prosecution; I will refer to these as exclusive determination schemes. ${ }^{14}$ Second, there are schemes in which the Security Council is given a limited amount of time to determine the existence of aggression. If the Security Council fails to make a determination, one way or the other, a different body may do so - perhaps the ICC itself, perhaps the General Assembly, and perhaps the ICJ in an advisory opinion. I will refer to these various arrangements as time-limited determination schemes.

Most proposals thus far discussed are exclusive determination schemes or time-limited determination schemes. Two other kinds of arrangements are also worthy of consideration, however. The Security Council might not be asked to determine aggression in a case before the ICC, but it might be given the exclusive authority to refer such cases to the ICC. I will refer to arrangements of this type as exclusive referral schemes. Though exclusive referral schemes have not been much discussed, they are in many ways preferable to exclusive determination schemes, while still meeting the political objectives of those who support exclusive determination schemes (i.e., they allow permanent members of the Security Council to veto ICC prosecutions).

Finally, there are arrangements under which the Security Council is not asked to make a determination of aggression in cases before the ICC and also does not have exclusive referral authority. I will refer to these arrangements as independent schemes. An independent scheme may make ICC prosecutions depend on a determination by the ICJ or the General Assembly, but a

13. For a consolidated text of some of the major proposals, see Discussion Paper on the Definition and Elements of the Crime of Aggression, Prepared by the Coordinator of the Working Group on the Crime of Aggression, Report of the Preparatory Commission for the International Criminal Court, Part II, U.N. Doc. PCNICC/2002/2/Add.2 (2002), available at http://www.un.org/law/icc/documents/aggression/aggressiondocs.htm (last visited Sept. 5, 2005). For discussion of the proposals, see Gurmendi, supra note 7; Clark, supra note 7; Schuster, supra note 4; Jennifer Trahan, Defining "Aggression": Why the Preparatory Commission for the International Criminal Court Has Faced Such a Conundrum, 24 LoY. L.A. INT'L \& COMP. L. REV. 439 (2002).

14. The ILC Draft Statute for an International Criminal Court made use of an exclusive determination scheme. Article 23(2) of that Statute provided, "A complaint of or directly related to an act of aggression may not be brought under this Statute unless the Security Council has first determined that a State has committed the act of aggression which is the subject of the complaint." ILC Draft Statute, supra note 4, at 84. 
determination by the Security Council is not required or even sought. In my opinion, an independent scheme would be most consistent with the Charter.

In addition to unresolved issues over the role of the Security Council, there remain difficult issues concerning the definition of the crime of aggression. Many proposals for the definition of aggression in the ICC Statute are based on General Assembly Resolution 3314, the "Definition of Aggression" resolution, ${ }^{15}$ which in turn is based on Article 2(4) of the U.N. Charter. Article 1 of the Definition annexed to General Assembly Resolution 3314 states: "Aggression is the use of armed force by a State against the sovereignty, territorial integrity or political independence of another State, or in any other manner inconsistent with the Charter of the United Nations, as set out in this Definition." 16 Article 2(4) of the Charter states: "All Members shall refrain in their international relations from the threat or use of force against the territorial integrity or political independence of any state, or in any other manner inconsistent with the Purposes of the United Nations."17

One outstanding definitional issue is how serious a use of force must be in order to qualify as aggression. There is consensus that "the use of force should be of a certain magnitude or gravity,"18 but there is disagreement over how to establish the proper threshold. ${ }^{19}$ Another outstanding issue is whether aggression must be committed by a state to give rise to individual criminal liability, or whether aggression by sub-state groups, not imputable to any state, can also be prosecuted. In most proposed definitions, aggression cannot be prosecuted unless it is imputable to a state, but this omission has been criticized. $^{20}$

Much valuable scholarship on the crime of aggression addresses both the role of the Security Council and the various definitional issues. In this article, I am less ambitious. I focus on the role of the Security Council, and I discuss the definitional issues only to the extent they bear on the role of the Security Council.

In Part II of this article, I argue that exclusive determination schemes those in which a Security Council determination of aggression is a precondition to prosecution for the crime of aggression - are in tension with several (1974).

15. G.A. Res. 3314 , U.N. GAOR, $29^{\text {th }}$ Sess., Supp No. 31 , at 142 , U.N. Doc. A/9631

16. Id. at 143.

17. U.N. ChARTER, art. 2(4). Charter Article 2(4) is in turm based on Article 10 of the Covenant of the League of Nations, which states, in part: "The Members of the League undertake to respect and preserve as against external aggression the territorial integrity and existing political independence of all Members of the League." LEAGUE OF NATIONS COVENANT, art. 10 (1926), reprinted in RUTH B. RUSSELL, A HISTORY OF THE UNITED NATIONS CHARTER 982 (1958).

18. Gurmendi, supra note 7, at 597 (reporting views in the Preparatory Commission).

19. Id.

20. Schuster, supra note 4, at 23; Grant M. Dawson, Defining Substantive Crimes Within the Subject Matter Jurisdiction of the International Criminal Court: What Is the Crime of Aggression?, 19 N.Y.L. SCH. J. INT'L \& COMP. L. 413, 444 (2000). 
important Charter-based principles. Such schemes erode the sovereign equality of states, push the Security Council into an inappropriate judicial role, and even threaten the Security Council's core Article 39 power to determine the existence of aggression in the context of its own decisions. In Part III, I respond to the argument that Article 39 of the U.N. Charter nevertheless mandates an exclusive determination scheme. Article 39 does disable all bodies but the Security Council from determining aggression as a way of triggering the Security Council's own responsibility and power to suppress aggression. However, Article 39 cannot be interpreted to disable all bodies but the Security Council from determining aggression outside the context of the Security Council's suppression of aggression. There are several situations in which the Charter provides for the determination of aggression by some body other than the Security Council; Article 39 itself indicates that the Security Council cannot be expected to determine the existence of stale aggression; and the ICJ has in the past determined the existence vel non of aggression, by way of determining the existence vel non of an "armed attack" under Article 51 of the Charter.

In Part IV, I offer some of my own proposals, based on the analysis previously given. I advocate a scheme in which the ICC seeks an advisory opinion from the ICJ in aggression cases, but in which failure to obtain such an opinion does not prevent further proceedings. I also propose additional powers for the Security Council in aggression cases, going beyond the Security Council's power to suspend ICC proceedings under ICC Article 16.

Unfortunately, it may be politically impossible to incorporate into the ICC Statute an independent scheme that leaves the five permanent members of the Security Council with no power to block prosecutions for the crime of aggression. There might have to be some compromise to protect the political interests of the permanent members. Against that eventuality, I offer a compromise proposal in which aggression cases can proceed through preliminary stages without Security Council approval, but in which Council approval is required before there can be a trial. Finally, I make an obvious proposal for resolving the legal issue over the exclusivity of the Security Council's power to determine aggression: That issue should be resolved by the ICJ in an advisory opinion.

\section{ChaRTER-BASEd ARguments Against ExClusive DETERMINATION SCHEMES}

In discussions of the role of the Security Council in prosecutions for the crime of aggression, it is often assumed that the ICC Statute could only be inconsistent with the U.N. Charter if the ICC Statute were amended to deny the Security Council an exclusive role in determining aggression for the ICC; if the ICC statute were amended to grant the Security Council an exclusive role, it is assumed, the ICC Statute would be fully consistent with the Charter. In fact, there are powerful Charter-based arguments against exclusive determination schemes. 


\section{A. Sovereign Equality}

First, an exclusive determination scheme would contravene the principle of sovereign equality set forth in Article 2(1) of the Charter. Article 2(1) states: "The Organization and its Members, in pursuit of the Purposes stated in Article 1 , shall act in accordance with the following Principles. ... The Organization is based on the principle of the sovereign equality of all its Members." ${ }^{21}$ Article 2(1) may be viewed with cynicism, in some quarters, because of the obvious tension between its principle of sovereign equality and the veto power granted to the permanent five members of the Security Council under Articles 23 and $27 .^{22}$ Nevertheless, sovereign equality is the first-listed Principle on which the United Nations is based. It would be disrespectful to the Charter, and to the United Nations, to assume that this principle is a joke, to be disregarded in considering whether various arrangements are consistent with the Charter.

The debate over the Security Council's role in prosecutions for the crime of aggression is not a debate about Security Council supremacy. Under Article 16 of the ICC Statute, the Security Council is already supreme in its authority over all pending prosecutions. The Security Council can prevent the ICC from proceeding with any case for a period of one year, and it can renew these oneyear "stop" orders indefinitely. Most proposals on the crime of aggression, including my own proposals discussed below, would give the Security Council even more extensive authority over ICC prosecutions for the crime of aggression. The real issue, then, is not Security Council supremacy, but veto supremacy. Will one permanent member, by exercising its veto, be able to shield its citizens and those of its allies from ICC prosecution? Will the five permanent members of the Security Council ("P5") acquire an effective immunity from prosecution for the crime of aggression, an immunity that will further set them apart from all other members of the United Nations?

Under the Charter, the P5 have effective immunity from enforcement action by the Security Council. They do not have effective immunity from adverse actions or recommendations by other organs of the United Nations, such as the International Court of Justice and the General Assembly. In practice, the question of Security Council exclusivity boils down to whether the P5 should be given an additional immunity from a new international institution, one they do not now possess.

The veto right of the permanent members of the Security Council is an obvious departure from pure sovereign equality. As Fassbender observes in his commentary on Article 2(1),

21. U.N. CHARTER, art. 2(1).

22. On tension between sovereign equality and the veto, see Bardo Fassbender and Albert Blechman, Article 2(1), in The ChaRTER OF THE UnITEd NATIONS: A COMmentaRY 77, 87 (Bruno Simma et al. eds., 2d ed. 2002). 
The records of the San Francisco Conference and the preceding diplomatic negotiations demonstrate that the prerogatives which the leading powers were given in the UN Charter - in particular permanent membership in the Security Council and the right of veto according to Art. 27(3) - were regarded as a painful, albeit necessary, exception to a true equality of status of all member States in the new organization.

So much was even admitted by the major powers themselves $^{23}$

The general principle of sovereign equality in Article 2(1) cannot of course be relied on to question the legality of the specific veto rights granted in the Charter. However, Article 2(1) can and should be used to resist further unnecessary departures from sovereign equality.

Many have commented on how unfair and unequal it would be if the five permanent members of the Security Council were allowed to shield their leaders from prosecution for the crime of aggression. ${ }^{24}$ It is important to realize that exclusive determination, with its consequent immunity for the P5, would contravene not only general principles of fairness and equality, but also the principle of sovereign equality in Article 2(1) of the Charter. The core of sovereign equality is juridical equality, or equality in law. ${ }^{25}$ If the P5 alone were allowed to block legal proceedings against their leaders, the damage to sovereign equality would be severe. Article 2(1) counsels against giving a major new juridical immunity to the P5, unless the Charter clearly requires this further departure from sovereign equality.

\section{B. Inappropriate Judicial Role}

A second Charter-based argument against exclusive determination schemes is that they would push the Security Council into an inappropriate judicial role. This argument, unlike the previous one, does not also apply to exclusive referral schemes. It does, however, apply to time-limited determination schemes.

23. Id. at 87.

24. See, e.g., Schuster, supra note 4, at 41; Paulus, supra note 6, at 21-22; Leila Nadya Sadat and S. Richard Carden, The New International Criminal Court: An Uneasy Revolution, 88 GEO. L.J. 381, 443 (2000).

25. The Report of the committee charged with drafting what became Article 2(1) states: 'The Subcommittee voted to keep the terminology 'sovereign equality' on the assumption and understanding that it conveys ... that states are juridically equal ..." Report of Rapporteur of Subcommittee 1/1/A to Committee I/1, Conference on International Organization, Doc. 723, June 1 , in The United Nations Conference on InTERnational Organization, Selected DOCUMENTS 483 (1946). On juridical equality as the core of sovereign equality, see Fassbender and Blechman, supra note 22 , at 85. 
The Security Council is a political body, and it has used the term "aggression" in its resolutions in a political way. The Security Council has not found the existence of aggression where aggression was most obvious, and it has found aggression in borderline cases. It has used the term "aggression" to describe behavior by very few states, though it has repeatedly cited two states (South Africa and Rhodesia) for aggression, and it has labeled Israel an aggressor twice. $^{26}$ The only consistent theme running through the Security Council's determinations of aggression is that the Security Council has used these determinations to send the message that it is angry at politically disfavored states or groups.

In 1990, Iraq invaded, occupied, and attempted to annex Kuwait. This was surely the most flagrant act of aggression in the post-World War II era, especially if we exclude acts by permanent members of the Security Council that the Security Council could not be expected to brand as aggression. Yet the Security Council did not label the invasion, occupation, and attempted annexation of Kuwait an act of aggression. In Resolution 660, the Security Council determined that "there exists a breach of international peace and security as regards the Iraqi invasion of Kuwait." 27 It was only when Iraq ordered the closure of foreign embassies in Kuwait that the Security Council passed a resolution "[s]trongly condemn[ing] aggressive acts perpetrated by Iraq against diplomatic premises and personnel in Kuwait, including the abduction of foreign nationals who were present in those premises."28

In the 1980's, the leadership of the Palestine Liberation Organization operated out of Tunisia. In 1985, Israel bombed the headquarters of the PLO in Tunisia, killing a reported 67 people. $^{29}$ In 1988, Israel sent a military team to assassinate a PLO official in Tunisia. The Israeli team killed the official and three other people. ${ }^{30}$ After both the 1985 incident and the 1988 incident, the Security Council passed resolutions condemning Israel's "aggression,",31 but taking no enforcement action against Israel.

The Security Council has once used the term "aggression" to describe the activities of a non-state group. In 1977, a group of mercenaries made an unsuccessful attempt to overthrow the government of Benin. In Resolution 405, the Security Council "strongly condemn[ed]" this "act of armed aggression

26. For a detailed summary of Security Council practice with respect to aggression, see Historical Review of Developments Relating to Aggression, Prepared by the Secretariat, 115121, Doc.PCNICC/2002/WGCA/L.1 (2002), available at http://www.un.org/law/icc/documents/aggression/aggressiondocs.htm (last visited Sept. 27, 2005).

27. U.N. SCOR, $45^{\text {th }}$ Sess., $2932^{\text {nd }}$ mtg., U.N. Doc. S/RES/660 (1990).

28. U.N. SCOR, $45^{\text {th }}$ Sess., $2940^{\text {th }} \mathrm{mtg}$., U.N. Doc. S/RES/667 (1990).

29. Bernard Weinraub, White House, in Shift, says Raid by Israel 'Cannot be Condoned', N.Y. Times, October 3, 1985, at Al.

30. Loren Jenkins, PLO Figure to be Buried in Damascus; Move Seen as an Effort to Heal Arafat-Assad Rift, WASH. POST, April 19, 1988, at A21.

31. U.N. SCOR, $40^{\text {th }}$ Sess., $2615^{\text {th }}$ mtg. At 23, U.N. Doc. S/RES/573 (1985); U.N. SCOR, 43th Sess., $2810^{\text {th }} \mathrm{mtg}$. At 15, U.N. Doc. S/RES/660 (1988). 
perpetrated against the People's Republic of Benin."32 One or more states may have been complicit in the mercenary attack on Benin, and the Security Council, in Resolution 405, reaffirmed a previous resolution in which it had condemned "any State which persists in permitting or tolerating the recruitment of mercenaries and the provision of facilities to them."33 But the Security Council's use of the term "armed aggression" in Resolution 405 did not appear to depend on the premise that the activities of the mercenaries could be imputed to some state.

So it is not aggression, under Security Council practice, when one state invades, occupies and annexes a neighboring state, but it is aggression when a state kills four people in a raid targeting a group that is waging an armed struggle against the state. The Security Council's use of the term "aggression", in the first 60 years of its existence, has been very far from the use one would expect from a judicial body. Yet if the ICC statute is amended to make a Security Council determination of aggression a prerequisite to any prosecution for aggression, the Security Council would be called upon to assume the functions of a judicial body. The Security Council would then determine a major issue of international criminal liability when it determined the existence of an act of aggression under Article 39. Inevitably, there would be great pressure on the Security Council to function as a court. The accused state would demand additional time to present its case. The Security Council would be called upon to view evidence and possibly hear witnesses. There would be extended legal arguments about the meaning of "aggression" and about historical precedents.

The Security Council could establish fact-finding commissions, as it has done in the past. Nevertheless, an ongoing responsibility to decide the major factual and legal issues in one species of international criminal case would be unlike any quasi-judicial responsibility the Security Council has thus far assumed.

The Security Council would not perform well if it were forced into a judicial role. Consistency is more important in a judicial body than in a political body. ${ }^{34}$ The political nature of the Security Council would make it difficult for the Security Council to make consistent decisions on aggression; the veto power would make consistency impossible. The Security Council could not label one of the permanent members an aggressor, even if that member had committed aggression that was, in every objective sense, far more blatant and grievous than the aggression committed by some other state that had been labeled an aggressor.

32. U.N. SCOR, Res. 405 , Dec., $32^{\text {nd }}$ Sess., $2005^{\text {th }}$ mtg. At 18 , U.N. Doc. S/INF/33 (1977).

33. Id.

34. While Article 59 of the ICJ Statute makes ICJ decisions non-precedential, the ICJ has displayed great consistency in its decisions, especially as compared to the Security Council. 
The veto power would also enable each of the permanent members to be the sole judge of a case against its leaders - in effect, to be the sole judge of its own case. $^{35}$ The principle that no one should be the judge of his or her own case (nemo debet esse judex in propria causa) is a bedrock principle of fair judicial procedure. ${ }^{36}$ Concededly, this principle is not as fully respected on the international plane as in some national legal systems. ${ }^{37}$ Probably the most serious compromise of the nemo judex principle concerns the enforcement of ICJ judgments. Under Article 94 of the Charter, the enforcement of ICJ judgments is entrusted to the discretion of the Security Council, so that the P5 are able to prevent the enforcement of judgments against them. ${ }^{38}$ Even here, however, the P5 cannot prevent ICJ cases from being brought against them in the first place (if they have in some way consented to jurisdiction). Article 94 's departure from the nemo judex principle is perhaps necessary; a further and even more serious departure should not be permitted unless it is also necessary.

The defect of pushing the Security Council into an inappropriate judicial role characterizes time-limited determination schemes as well as exclusive determination schemes. Suppose that the Security Council has a limited amount of time (six months or a year) to determine aggression, but that some other body can determine aggression if the Security Council makes no decision. The Security Council would still be subject to pressure to assume a judicial role. And while inaction by the Security Council would be easier in a timelimited determination scheme, it is unlikely that the Security Council would completely ignore a request that it determine aggression in a pending ICC case. There are now approximately 100 parties to the ICC Statute, including two permanent members of the Security Council, Britain and France. ${ }^{39}$ A request by the ICC that the Security Council determine aggression would undoubtedly be placed on the agenda of the Security Council and receive great attention.

My discussion of Security Council practice in determining the existence of aggression should not be taken as a general indictment of the Security Council. The Security Council undoubtedly plays a positive role in maintaining international peace and security, as compared to a world with no Security

35. Sadat and Carden, supra note 24, at 443.

36. In re Murchison, 349 U.S. 133, $136(1955)$ ("[N]o man can be a judge in his own case.").

37. See Tapio Puurunen, The Legislative Jurisdiction of States Over Transactions in Intemational Electronic Commerce, 18 J. MARSHALL J. COMPUTER \& INFO. L. 689, 736 n. 196 (2000); Christopher A. Ford, Judicial Discretion in International Jurisprudence, 5 DUKE J. COMP. \& INT'L L. 35, 81-82 (1994).

38. Article 27(3) of the Charter states that "in decisions under Chapter VI ... a party to a dispute shall abstain from voting." U.N. CHARTER, art. 27(3). However, the Chapter VI abstention rule does not apply to the enforcement of ICJ decisions under Article 94. See Stefan Brunner, Article 27, in ThE ChARTER OF THE UNITED NATIONS: A COMMENTARY 503 (Bruno Simma et al. eds., 2d ed. 2002).

39. International Criminal Court, Assembly of States Parties: The States Parties to the Rome Statute, available at http://www.icc-cpi.int/asp/statesparties.html (last visited Sept. 28, 2005). 
Council. Given the realities of the international political system, the Security Council is also best suited to determine aggression in the context of the Security Council's own suppression of aggression (which, as discussed below, is the context of Article 39). The Security Council is not, however, well suited to determine aggression in the context of an ICC case.

The U.N. Charter established the Security Council and the General Assembly as political bodies and the ICJ as a judicial body. It would be inconsistent with the Charter to push the Security Council into a judicial role to which it is not at all suited.

To be sure, the behavior of the Security Council will probably change somewhat when the ICC begins to exercise its jurisdiction over the crime of aggression, even if the Security Council is not called upon to make determinations of aggression in the context of ICC cases. Until now, the use of the term "aggression" by the Security Council has had little or no practical significance. The Security Council has the same vast enforcement powers under Chapter VII whether it determines the existence of a threat to the peace, a breach of the peace, or an act of aggression. It is far preferable to be called an aggressor and have the Security Council wag its finger at you (as with Israeli raids on PLO targets in Tunisia) than to be called a breacher of the peace and have the Security Council impose economic sanctions and authorize the use of force against you (as with the Iraqi invasion of Kuwait). ${ }^{40}$

When there is a real possibility of prosecution for the crime of aggression, the Security Council's use of the term "aggression" is bound to be affected. There may be less inclination to find aggression in borderline cases. Inevitably, though, there will still be inconsistency and political self-judging, due to the political character of the Security Council and the veto of the permanent members.

It might be thought that the objections I have thus far raised to exclusive determination schemes are in reality one objection: the veto. I would say, rather, that the veto makes exclusive determination objectionable on more than one Charter-based ground. The veto makes exclusive determination a violation of sovereign equality, and the veto also makes it particularly inappropriate to entrust a judicial decision to a political body. These objections to exclusive determination are, however, mutually reinforcing. As noted, the core of sovereign equality is juridical equality. By inappropriately allowing for the use of the veto to bar a judicial proceeding, exclusive determination schemes would cause one of the most serious possible violations of sovereign equality.

\section{Prescribing Standards for the Security Council}

Another Charter-based argument against exclusive determination schemes is that they would threaten the Security Council's own genuine Article

40. Presumably, the United States would have vetoed the resolutions calling Israel an aggressor if those resolutions could have led to international criminal liability for Israeli leaders. 
39 role of deciding for itself, in the context of its own decisions, what constitutes aggression. Once again, this objection applies as well to timelimited determination schemes, but not to exclusive referral schemes.

What standards would the Security Council use in determining aggression in an ICC case? One never knows, but there would be great pressure on the Security Council to apply the definition in the ICC Statute, once that definition is finally thrashed out. Those members of the Security Council who are parties to the ICC Statute could certainly be expected to support using the ICC definition. If the Security Council did not attempt to apply the ICC Statute, it would find itself triggering prosecution in cases that should not be prosecuted under the ICC Statute, and withholding from prosecution cases that should be prosecuted. Of course, the Security Council could not be expected to apply the standards in the ICC Statute if a permanent member was accused of aggression, but in cases in which no veto is exercised, the ICC Statute would seem the most likely source of standards.

I argue below that Article 39 of the Charter cannot bear the meaning that the Security Council must be the sole body to determine aggression in every context. Surely, however, the Security Council must determine the existence of aggression in the context of its own decisions. The phrase, "The Security Council shall determine..." in Article 39 does not prohibit any body except the Security Council from determining aggression, but it does prohibit any body except the Security Council from determining aggression for the Security Council. Inaugurating a procedure that would predictably lead to the Security Council applying some other body's definition of aggression (where it applies any definition at all) is in tension with Article 39 . Moreover, it is hardly deferential or respectful to the Security Council to deputize it to apply ICC law.

The General Assembly's 1974 "Definition of Aggression" resolution was intended as a guide for the Security Council. However, Article 4 of the Definition annexed to Resolution 3314 states: "The acts enumerated above are not exhaustive and the Security Council may determine that other acts constitute aggression under the provisions of the Charter." ${ }^{41}$ A similar provision in the ICC Statute's definition of aggression is unlikely in the extreme, as it would violate the principle of no crime without law (nullum crimen sine lege), recognized in Article 22 of the ICC Statute. ${ }^{42}$ Also, the Security Council has essentially ignored the General Assembly's definition of aggression. The Security Council could easily ignore the General Assembly's definition, as it was not called upon to determine aggression for the General Assembly's purposes. The Security Council would not be able to ignore the ICC's definition of aggression if it is called upon to determine aggression as an issue in ICC cases.

41. G.A. Res. 3314, supra note 15, at 143.

42. ICC Statute, supra note 1, art. 22. 


\section{ARTICle 39 Does Not MAKe The SeCurity CouncIl The Sole DETERMINER OF AGGRESSION}

While exclusive determination schemes are in tension with important Charter-based principles, that tension might have to be borne if Article 39 truly required an exclusive determination scheme. Fortunately, it does not.

The argument for exclusive determination presents itself as something close to a syllogism. Under Article 39, the Security Council "shall determine the existence of any . . . act of aggression . . .."43 Therefore, by negative implication, no other body may determine the existence of aggression. But the implication of exclusivity from Article 39 is not nearly as broad as the advocates of exclusive determination would like to believe. A straightforward analysis of the Charter reveals that the Security Council's authority to determine the existence of aggression cannot be completely exclusive. There are two circumstances in which the Charter explicitly calls for some body other than the Security Council to determine the existence of aggression; Article 39 itself indicates that the Security Council cannot be expected to determine the existence of stale aggression; and the dispute-resolution provisions of the Charter indicate that the ICJ must be able to determine aggression in at least some cases. Under Article 39, the Security Council's power to determine the existence of aggression is tied to the Security Council's power to suppress aggression. The true negative implication of Article 39 is that no body other than the Security Council may determine aggression as a step toward the Security Council's own suppression of aggression.

\section{A. Determination of Aggression Under Article 53 and Article 51}

Article 53 of the Charter states that no enforcement action shall be taken under regional arrangements without the authorization of the Security Council. However, there is a now-obsolete exception for "regional arrangements directed against renewal of aggressive policy on the part of [the defeated Axis powers in World War II], until such time as the Organization may, on request of the Governments concerned, be charged with the responsibility for preventing further aggression by such a state." Under this exception, there could be enforcement action under regional arrangements against the Axis powers, without the approval of the Security Council, and the Security Council would have no authority to review these actions without the consent of the victorious Allied powers.

Article 53 alone is not very helpful in gauging the exclusivity of the Security Council's power to determine aggression under Article 39 . When the United Nations was founded, there was unfinished business from World War II. Even though the Allies were given authority to determine aggression, or

43. U.N. ChARTER, art. 39.

44. U.N. CharTER, art. 53., 11 (emphasis added). 
renewal of aggressive policy, by the Axis, this could theoretically be the only exception to the Security Council's exclusive power to determine aggression under Article 39. It is noteworthy, however, that the Allies' power to determine aggression under Article 53, through regional arrangements, is the only place in the Charter where there is a power to determine aggression, binding on other states, and that power actually makes a difference. As noted, it has thus far made no real difference, under Article 39, whether the Security Council determines the existence of a threat to the peace, a breach of the peace, or an act of aggression: The Security Council's enforcement powers are the same upon all three determinations. By contrast, the extra authority of "regional arrangements" under Article 53 depends on a determination by the Allies that there has been a "renewal of aggressive policy" by an Axis power, or that the regional arrangements are directed against such renewal.

The second explicit Charter exception to Article 39 exclusivity is more important. Under Article 51, states retain the right of individual or collective self-defense "if an armed attack [French: agression armée] occurs against a Member of the United Nations, until the Security Council has taken measures necessary to maintain international peace and security. ${ }^{45}$ Thus, states themselves make an initial determination of aggression under Article 51, subject to review by the Security Council. ${ }^{46}$ States can defend themselves, and they can even go to war on behalf of other states that have been attacked, based on their own initial determination that an armed attack has occurred.

There is some debate over whether the term "armed attack" in Article 51 has the same meaning as the term "aggression," or "act of aggression," in Article $39 .{ }^{47}$ In the Nicaragua case, ${ }^{48}$ discussed below, the ICJ treated the term "armed attack" as synonymous with the term "aggression." In the French text of the Charter, the term corresponding to "armed attack" in Article 51 is "agression armée," 49 further suggesting that armed attack and aggression are the same thing (or at least, that armed attack and armed aggression are the same thing).

In my opinion, the main difference between the "armed attack" of Article 51 and the "act of aggression" of Article 39 is that the term "act of aggression" has whatever meaning the Security Council, for political reasons, chooses to give it, while the term "armed attack" has a more definite legal meaning, especially after the Nicaragua case. But insofar as we try to give a more objective, juridical meaning to the term "act of aggression" in Article 39, that

45. U.N. CHARTER, art. 51.

46. See Luigi Condorelli, Conclusions Générales, in The INTERnational CrIMINAL COURT AND THE CRIME of AGgRession 160 (Mauro Politi \& Giuseppe Nesi eds., 2004).

47. See Albrecht Randelzhofer, Article 51, in THE ChARTER OF THE UNITED NATIONS: A COMMENTARY 795 (Bruno Simma et al. eds., 2d ed. 2002) (denying identity of terms).

48. Military and Paramilitary Activities in and Against Nicaragua (Nicar. v. U.S.), Merits, 1986 I.C.J. 14 (June 27, 1986).

49. Charte Des Nations UNIES, art. 51, available at http://www.un.org/french/aboutun/charte/index.html (last visited Sept. 28, 2005). 
term is obviously very close, if not identical, to the term "armed attack" in Article 51.

It might be thought that no matter how close in meaning the two terms are, the initial determination of states as to armed attack under Article 51 does not rebut Article 39's implication of exclusivity because the precise term "aggression" is not used in the English text of Article 51. I will return to this objection later.

Under Article 51, the Security Council's power to determine aggression is supreme, but not exclusive. Pending a determination by the Security Council, states can make their own determination of aggression. This arrangement makes it more plausible that the ICC can determine aggression, consistent with the Charter, especially given the Security Council's authority to suspend ICC proceedings under Article 16 of the ICC Statute. ${ }^{50}$

\section{B. Stale Aggression Outside Article 39}

Article 53's exception to exclusive determination is interesting, and Article 51's exception is telling, as argued further below. But the main obstacle to total exclusivity is Article 39 itself. Read fairly, Article 39 indicates that the Security Council cannot be expected to determine the existence of stale aggression, aggression that has occurred in the past and as to which the Security Council sees no need for action. Article 39 states, in full: "The Security Council shall determine the existence of any threat to the peace, breach of the peace, or act of aggression and shall make recommendations, or decide what measures shall be taken in accordance with Articles 41 and 42, to maintain or restore international peace and security." 51

Article 39 is the gateway to Chapter VII of the Charter, which is titled "Action with respect to Threats to the Peace, Breaches of the Peace, and Acts of Aggression." Article 39 has a Determination Clause ("The Security Council shall determine...") and an Enforcement Clause ("... and shall make recommendations, or decide what measures shall be taken...") Those who advocate exclusive determination focus on the Determination Clause. I question whether the Determination Clause, even if read in isolation, could be interpreted to mean that no body but the Security Council shall ever determine aggression in any setting. But when the Determination Clause is read in the context of the Enforcement Clause, it is clear that the Security Council's authority to determine aggression is tied inextricably to the Security Council's authority and responsibility to suppress aggression.

Under the literal language of Article 39, the Security Council cannot determine the existence of aggression without making recommendations or

50. In Part IV, I propose that the ICC Statute be amended to give the Security Council additional authority over ICC proceedings involving the crime of aggression

51. U.N. ChARTER, art. 39 (emphasis added).

52. U.N. CHARTER, ch. VII (emphasis added). 
taking measures to maintain or restore international peace and security. Conversely, if the Security Council sees no need to make recommendations or take measures to maintain or restore international peace and security, it would seem that the Security Council cannot determine the existence of aggression under Article 39.

Consider a hypothetical case of alleged aggression, loosely modeled on Argentina's invasion of the Falklands but occurring after the ICC begins exercising jurisdiction over the crime of aggression. State A invades State B's territory. State $B$ repulses the invasion. This military defeat leads to the collapse of the military dictatorship in State A and to the restoration of democracy in that country. State A gives up any claim to the territory of State B (something that has not happened with Argentina and Britain.) Every possible threat to international peace and security from State A's invasion of State B has disappeared. Now the ICC prosecutor wants to charge the former military leaders of State A with the crime of aggression.

In such a case, the Security Council might see no reason to do anything to maintain or restore international peace and security. Arguably, then, the Security Council could not legitimately determine, in retrospect, the existence of aggression under Article 39. So if a determination of aggression under Article 39 were a precondition to prosecution for the crime of aggression before the ICC, this hypothetical alleged aggression could not be prosecuted, even if all members of the Security Council supported prosecution - as long as they took seriously the literal requirement of Article 39 that a determination of aggression be followed by recommendations or measures to maintain or restore international peace and security.

It could be argued that even in the most tranquil peace, prosecution of those responsible for past aggression is a measure to "maintain" peace and security. This seems a strained reading of Article 39, especially in light of the reference in Article 1(1) to the "suppression of acts of aggression or other breaches of the peace." A more natural reading is that the Security Council acts under Article 39 in response to some disruption. Indeed, the most natural reading of Article 39 may be that the Security Council does not "maintain" international peace and security in response to an act of aggression; the Security Council "maintains" peace in response to a threat to the peace, but it "restores" peace in response to a breach of the peace or an act of aggression. ${ }^{54}$

Granted, the Security Council would have the power to give a strained interpretation to the Enforcement Clause of Article 39, just as it has the power

53. U.N. Charter, art. 1(1) "The Purposes of the United Nations are... To maintain international peace and security, and to that end: to take effective collective measures for the prevention and removal of threats to the peace, and for the suppression of acts of aggression or other breaches of the peace." Id.

54. In Article 1(1), the suppression of aggression is done in order to "maintain international peace and security," but the context of Article 39 ("maintain or restore") suggests that the word "maintain" may be used there in a narrower sense. 
to give what some consider a strained interpretation to the Determination Clause, finding threats to the peace where some believe there are no threats to the peace. ${ }^{55}$ But despite arguments over the Security Council's application of Article 39, the Security Council has not completely drained Article 39's terms of their ordinary meaning. While the Security Council may have the power to determine that a ham sandwich poses a threat to the peace, the Security Council has not yet done so. It is perfectly conceivable that some members of the Security Council may take the view, in a case of stale aggression, that if there is no need to suppress aggression, there is no occasion to determine aggression.

Many proposals for the ICC's exercise of jurisdiction over the crime of aggression require that the Security Council act under Chapter VII when making a determination of aggression precedent to an ICC prosecution for aggression. This requirement is included in both exclusive schemes and nonexclusive schemes. The foregoing discussion suggests that if Security Council action must be a prerequisite, the requirement of action under Chapter VII is a mistake. If the Security Council is called upon (as I think, inappropriately) to make a determination of past aggression, it should be able to do so even when the Council's members see no need for enforcement action. ${ }^{56}$

\section{Dispute Resolution Under Chapter VI}

While Article 39 appears to disable the Security Council from determining the existence of stale aggression under Chapter VII, the provisions of Chapter VI of the Charter appear to enable the ICJ and other adjudicative bodies to determine the existence of aggression in at least some cases. Article 33(1) provides: "The parties to any dispute, the continuance of which is likely to endanger the maintenance of international peace and security, shall, first of all, seek a solution by negotiation, enquiry, mediation, conciliation, arbitration, judicial settlement, resort to regional agencies or arrangements, or other peaceful means of their own choice." 57 Article 36 provides that in making recommendations in cases under Chapter VI, the Security Council "should take into consideration any procedures for the settlement of the dispute which have already been adopted by the parties," and that the Security Council "should also take into consideration that legal disputes should as a general rule be referred

55. On controversies over the Determination Clause, see Inger Osterdahl, THREAT TO THE PEACE: THE INTERPRETATION BY THE SECURITY COUNCIL OF ARTICLE 39 OF THE UN CHARTER (1998).

56. A requirement that the Security Council act under Chapter VII is already included in existing provisions of the ICC Statute. Article 16 requires that the Security Council act under Chapter VII when suspending an ICC proceeding, and Article 13 requires that the Security Council act under Chapter VII when referring a case to the ICC. The requirement of action under Chapter VII for an Article 16 "stop" order makes sense: The Security Council should not be able to stop ICC proceedings unless the Security Council believes there is a threat to the peace. The requirement of Chapter VII action for an Article 13 referral may indicate an expectation that the Security Council will use Article 13 referrals to deal with ongoing conflicts.

57. U.N. Charter, art. 33(1). 
by the parties to the International Court of Justice in accordance with the provisions of the Statute of the Court."58

The existence of aggression can certainly be an issue in a legal dispute governed by the provisions of Chapter VI. In some cases, discussed below, a legal dispute over aggression may overlap with Security Council treatment of a conflict under Chapter VII. But in other cases, there can be a legal dispute over aggression where Chapter VII is not in the picture. A number of treaties prohibit aggression; a tribunal might be called upon to determine the existence of past aggression when applying or interpreting such a treaty. Aggression can also be an issue in legal disputes over title to territory.

In 2001, the ICJ resolved boundary disputes between Bahrain and Qatar. ${ }^{59}$ Bahrain claimed, in that case, that Qatar had obtained the territory of Zubarah in 1937 through "aggression." Security Council prerogative, I trust, would say that the Security Council alone may determine, in a boundary dispute, whether aggression occurred in 1937.

\section{Has the ICJ Ever Determined the Existence of Aggression?}

Aggression clearly can be a legal issue, to be resolved by adjudicative bodies under Chapter VI of the Charter rather than by the Security Council under Chapter VII. For this reason alone, therefore, the argument for total exclusivity is unconvincing. The argument for total exclusivity would be even less convincing if the ICJ had ever actually determined the existence of aggression.

It is easy to find, in ICJ cases, allegations by states that other states have committed aggression. It is harder to find ICJ determinations of aggression. The ICJ generally does not frame the issue as whether a state has committed aggression, even if the issue is so framed by one of the parties. In cases involving the use of force, the ICJ generally frames the issue, not surprisingly, as whether a state has used force in violation of Article 2(4) of the Charter.

Undoubtedly, there is considerable overlap between aggression and a use of force in violation of Article 2(4). Any definition of aggression in the ICC statute is likely to be based on Article 2(4) or on the General Assembly's "Definition of Aggression" resolution," which itself was based on Article 2(4). Aggression, however, is generally taken to be a narrower category than unlawful use of force; it is so taken by the ICJ itself, as noted below. So it

58. U.N. Charter, art. 36.

59. Maritime Delimitation and Territorial Questions (Qatar v. Bahrain), 2001 I.C.J. 40 (Mar. 16, 2001).

60. "Bahrain maintains that Qatar's 'aggression' against Zubarah was an unlawful use of force from which no legal rights could arise, supporting its contention by reference to various international instruments from the relevant period dealing with the illegal use of force." $I d$. at 76.

61. G.A. Res. 3314, U.N. GAOR, $2^{\text {th }}$ Sess., Supp. No. 19, U.N. Doc. A/9619 (1974). 
cannot be said that in determining the existence vel non of an unlawful use of force, the ICJ has necessarily determined the existence of aggression.

Nevertheless, the ICJ has determined the existence vel non of an armed attack within the meaning of Article 51, and it has identified armed attack with aggression. Therefore, in my view, the ICJ has determined aggression. ${ }^{62}$ The three most relevant cases here are the Nicaragua case, ${ }^{63}$ the Oil Platforms case, ${ }^{64}$ and the Armed Activities case. ${ }^{65}$

\section{Nicaragua Case}

In its 1986 judgment in the Nicaragua case, the ICJ held that the United States had used unlawful force against Nicaragua in violation of international customary law that was, in essence, identical to Article 2(4) of the Charter. The United States had used unlawful force, the Court held, by mining Nicaraguan ports and by several naval attacks "on Nicaraguan ports, oil installations and a naval base." 66 These operations were conducted or organized by the CIA. ${ }^{67}$ In addition, the Court held that the United States had unlawfully used or threatened force by arming and training the Nicaraguan "Contras" who were seeking to overthrow the government of Nicaragua. ${ }^{68}$

It has been suggested that the ICJ determined, in the Nicaragua case, that the United States committed aggression against Nicaragua. ${ }^{69}$ I disagree with this assessment, for reasons explained below. The Court's determination of aggression in the Nicaragua case came, rather, in the course of its evaluation of Nicaragua's conduct.

The United States contended, before it stopped participating in the proceedings, that its actions against Nicaragua had been justified under a theory of collective self-defense. The United States claimed that it had been defending El Salvador, Honduras and Costa Rica against attacks and subversion from Nicaragua. In evaluating this American defense, the ICJ applied international customary law that it once again found to be identical, in essence, to a provision of the Charter, in this case the provision in Article 51 that states retain the right

62. For a less opinionated discussion that covers some of the same ground as my own, see generally, Historical Review of Developments Relating to Aggression, Prepared by the Secretariat 128-135, U.N. Doc. PCNICC/2002/WGCA/L.1 (2002), available at http://www.un.org/law/icc/documents/aggression/aggressiondocs.htm (last visited Sept. 1, 2005).

63. Military and Paramilitary Activities in and Against Nicaragua (Nicar. v. U.S.), Merits, 1986 I.C.J. 14 (June 27, 1986).

64. Oil Platforms (Iran v. U.S.), 2003 I.C.J. 161 (Nov. 6, 2003).

65. Case Concerning Armed Activities on the Territory of the Congo (Democratic Republic of the Congo v. Uganda), Merits, 2005 I.C.J. (Dec. 19, 2005).

66. Nicaragua, Merits, 1986 I.C.J. 14, at 1 227, 292(4), 292(6).

67. Id. at $1976-86$.

68. Id. at $\{1228,292(4)$.

69. Linda Jane Springrose, Aggression as a Core Crime in the Rome Statute Establishing an International Criminal Court, 1999 ST. LOUIS-WARSAW TRANS'L L.J. 151, 167 (1999). 
to individual or collective self-defense against an "armed attack."70 The Court therefore undertook to determine the existence of an armed attack by Nicaragua. As it stated, "For the Court to conclude that the United States was lawfully exercising its right of collective self-defence, it must first find that Nicaragua engaged in an armed attack against El Salvador, Honduras or Costa Rica."71

It was in connection with this inquiry that the ICJ, in my view, determined the existence of aggression in the relevant sense. The Court equated armed attack with aggression in two parts of its opinion. In paragraph 195, it stated that the "Definition of Aggression" in General Assembly Resolution 3314 "may be taken to reflect customary international law" on what constitutes an armed attack. ${ }^{72}$ Therefore, according to the Court, an armed attack includes "the sending by or on behalf of a State of armed bands, groups, irregulars or mercenaries, which carry out acts of armed force against another State" of sufficient gravity. ${ }^{73}$ This is an armed attack, the Court decided, because it is defined as aggression in General Assembly Resolution $3314 .^{74}$

In paragraph 191, the Court referred to another General Assembly resolution, Resolution 2625, the "Declaration on Principles of International Law concerning Friendly Relations and Cooperation among States in accordance with the Charter of the United Nations." ${ }^{75}$ The Court stated that Resolution 2625 includes a description of "less grave" violations of the customary-law prohibition on the use of force, in addition to a description of more grave violations that constitute armed attack or aggression. ${ }^{76}$ In discussing Resolution 2625, the Court once again equated armed attack and aggression:

As regards certain particular aspects of the principle in question, it will be necessary to distinguish the most grave forms of the use of force (those constituting an armed attack) from other less grave forms. In determining the legal rule which applies to these latter forms, the Court can again draw on the formulations contained in the Declaration on Principles of International Law concerning Friendly Relations and Cooperation among States in accordance with the Charter of the United Nations (General Assembly resolution 2625(XXV), referred to above). As already observed, the adoption by

70. Nicaragua, Merits, 1986 I.C.J. 14, at 19 193-195.

71. Id. at 9229.

72. Id. at 9195. (1974)).

73. Id. (quoting G.A. Res. 3314 , U.N. GAOR $29^{\text {th }}$ Sess., Supp. No 19 , U.N. Doc A.9619

74. Id.

75. G.A. Res. 2625, U.N. GAOR, $25^{\text {th }}$ Sess., Supp. No 18, U.N. Doc. A/8018 (1970).

76. Nicaragua, Merits, 1986 I.C.J. 14, at 191. 
States of this text affords an indication of their opinio juris as to customary international law on the question. Alongside certain descriptions which may refer to aggression, this text includes others which refer only to less grave forms of the use of force ....7

Thus, the terms "armed attack" and "aggression" are used, interchangeably, to refer to more grave forms of the use of force, as opposed to less grave forms that do not constitute armed attack or aggression.

In the Nicaragua case, the Court refused to find that Nicaragua had engaged in an armed attack against El Salvador, Honduras, or Costa Rica. ${ }^{78}$ The Court held that Nicaragua's alleged assistance to rebels in El Salvador, "in the form of the provision of weapons or logistical or other support," did not constitute an armed attack. ${ }^{79}$ Nicaragua had also made some transborder military incursions into Honduras and Costa Rica. As to these incursions, the Court indicated that there was insufficient evidence to determine whether they amounted to an armed attack. ${ }^{80}$ The Court also found that the behavior of Honduras and Costa Rica, at the time of the challenged U.S. actions, did not support the view that these states had seen themselves as victims of an armed attack by Nicaragua and had asked the United States to come to their defense. ${ }^{81}$ Based on these rulings, the Court rejected the U.S. claim of collective selfdefense and determined that the United States had used unlawful force.

Did the Court in the Nicaragua case determine that the United States had committed aggression? In my view, no. The Court emphasized the distinction between an armed attack (equated to aggression) and the mere unlawful use of force. ${ }^{82}$ Therefore, the Court's determination that the United States had used unlawful force was not a determination that it had committed aggression. The Court did, however, determine the existence vel non of aggression by Nicaragua, by determining whether Nicaragua had engaged in an armed attack that justified the United States' use of force.

\section{Oil Platforms Case}

In Oil Platforms, ${ }^{83}$ the ICJ once again undertook to determine whether the United States had faced an armed attack and had therefore been justified in taking military action in self-defense. ${ }^{84}$ This time the target of U.S. military

77. Id. (emphasis added).

78. Id. at $99195,231$.

79. Id. at $\uparrow 195$.

80. Id. at 9231.

81. Id. at $19232-234$.

82. Id. at I $191,195$.

83. Oil Platforms (Iran v. U.S.), 2003 I.C.J. 161.

84. For an overview of this case, see Pieter H.F. Bekker, The World Court Finds that U.S. Attacks on Iranian Oil Platforms in 1987-1988 Were Not Justifiable as Self-Defense, but the 
action was Iran. The Oil Platforms case grew out of the 1980-1988 Iran-Iraq war. Toward the end of that war, Iran began attacking neutral shipping in the Persian Gulf. These attacks led to military friction between the United States and Iran. In 1987 and again in 1988, the United States destroyed Iranian oil platforms. The United States claimed at the time that it was acting in selfdefense.

Iran brought a case against the United States before the ICJ, basing jurisdiction on a 1950's treaty of friendship between Iran and the United States, and claiming that the U.S. attacks had violated the treaty. In the course of resolving issues under the U.S.-Iran treaty (not discussed here), the ICJ evaluated the U.S. claim of self-defense. ${ }^{85}$ The ICJ ruled that this claim depended, inter alia, on whether Iran had made an armed attack on the United States within the meaning of Article 51 of the Charter. The Court quoted with approval a statement from the Nicaragua decision that in evaluating claims of self-defense, "it is necessary to distinguish "the most grave forms of the use of force (those constituting an armed attack) from other less grave forms." " 86

The ICJ held that the United States had not proved that Iran made an armed attack on it. In defense of its 1987 military action, the United States relied on a number of incidents, including a missile strike on a U.S.-flagged ship; purported fire on U.S. helicopters from Iranian oil platforms; and the mining of a U.S.-owned ship and a U.S.-flagged ship. In defense of its 1988 military action, the United States relied on the mining of a U.S. warship, resulting in injuries to the crew and damage to the ship. As to some of the incidents relied on by the United States, the ICJ held that the United States had not proved Iran's involvement. As to some, the Court held that the United States had not proved that Iran was specifically targeting the United States (unlike in the Nicaragua case, the United States in Oil Platforms was claiming only individual self-defense, not collective self-defense). The ICJ also expressed some doubt that the incidents that preceded each American military operation were "grave" enough, alone or in combination, to constitute an armed attack. ${ }^{87}$ The Court therefore rejected the U.S. claim of self-defense, though it ruled in favor of the United States, on the merits of Iran's treaty claim, on other grounds.

In my opinion, the ICJ determined the existence vel non of aggression in Oil Platforms, by way of determining the existence vel non of an armed attack by Iran. In Nicaragua, the ICJ had equated armed attack and aggression. In Oil Platforms, the ICJ adhered to the concept of armed attack it had laid down

United States Did Not Violate the Applicable Treaty with Iran, ASIL Insights (November, 2003).

85. In the terms of the treaty, the U.S. claim was that its actions were "necessary to protect essential security interests", but the ICJ applied Charter law to evaluate this claim. Oil Platforms, 2003 I.C.J. 161 at $\ 32$.

86. Id. at I 51, (quoting Nicaragua, Merits, 1986 I.C.J. 14 at I 191).

87. Oil Platforms, 2003 I.C.J. 161 at 994,72 . However, the Court did say that it "does not exclude the possibility that the mining of a single military vessel might be sufficient to bring into play the "inherent right of self-defence." Id. at 972. 
in Nicaragua, and therefore, it is fair to assume, continued to equate armed attack and aggression.

\section{The Armed Activities case}

Shortly before this Article went to press, the ICJ handed down its judgment in Armed Activities on the Territory of the Congo (Congo $v$. Uganda $)^{88}$ In this case, the Court once more equated armed attack and aggression, en route to denying Uganda's claim of self-defense: "The attacks [on Uganda] did not emanate from armed bands or irregulars sent by the [Democratic Republic of the Congo] or on behalf of the DRC, within the sense of ... General Assembly resolution 3314... on the definition of aggression...."89 The Armed Activities case is therefore yet another instance in which the ICJ has, in my opinion, determined the existence vel non of aggression.

\section{The Tehran Case and The Wall Case}

Two other ICJ cases are also worth mentioning in this connection. In United States Diplomatic and Consular Staff in Tehran, ${ }^{90}$ the ICJ referred to the 1979 seizure of the American embassy in Tehran, by a mob of Iranians, as an "armed attack." 91 This, however, was before the ICJ had equated armed attack and aggression in Nicaragua. I therefore would not claim that the ICJ determined the existence of aggression in the Tehran case.

In its 2004 advisory opinion on Israel's construction of a wall (or separation barrier) in the West Bank, ${ }^{92}$ the ICJ addressed Israel's claim that in building a wall to keep out suicide bombers, it was exercising its right of selfdefense under Charter Article 51. Israel did not participate in this case. However, in a General Assembly debate on the same issue, Israel had relied on Security Council resolutions 1368 (2001) and 1373 (2001), which explicitly recognized the U.S. right of self-defense in response to the September 11, 2001 attacks.

In its advisory opinion, the ICJ rejected Israel's claim of self-defense. ${ }^{93}$ The Court opined that as any attacks on Israel originated in Israeli-controlled

88. Case Concerning Armed Activities on the Territory of the Congo (Democratic Republic of the Congo v. Uganda), Merits, 2005 I.C.J. (Dec. 19, 2005).

89. Id. at $\ 146$ (emphasis added).

90. United States Diplomatic and Consular Staff in Tehran (U.S. v. Iran), 1980 I.C.J. 3 (May 24).

91. Id. at $9114,57,64,91$.

92. Legal Consequences of the Construction of a Wall in the Occupied Palestinian Territory, Advisory Opinion, 2004 I.C.J., 43 I.L.M. 1009 (July 9, 2004). [hereinafter, Wall].

93. Wall, at If 138-141. The ICJ did note that "Israel has to face numerous indiscriminate and deadly acts of violence against its civilian population. It has the right, and indeed the duty, to respond in order to protect the life of its citizens." But, said the ICJ, "[t]he measures taken are bound... to remain in conformity with applicable international law." Id. at $\uparrow 141$. 
territory, they could not be armed attacks within the meaning of Article 51.94 The Court also suggested that an armed attack, within the meaning of Article 51 , must be an attack by another State, or one imputable to another State. ${ }^{95}$ The ICJ therefore seemed to imply, remarkably, that the September 11 attacks on the United States were armed attacks, within the meaning of Article 51, only to the extent that those attacks were imputable to Afghanistan. The ICJ's suggestion in the Wall case that an armed attack can be committed only by a state may be inconsistent with its use of the phrase "armed attack," in the Tehran case, to describe the attack on the American Embassy in Tehran.

In any event, it is clear that the ICJ has determined the existence vel non of an armed attack, within the meaning of Article 51. Let us therefore return to the issue of whether "armed attack" and "aggression" are the same thing. If they are the same thing, then the ICJ has determined aggression, and the argument that no entity except the Security Council may determine aggression is further weakened.

It might be argued that however much the ICJ equated armed attack and aggression in the Nicaragua case, the term "armed attack" in Article 51 does not contain the word "aggression," whereas the term "crime of aggression" in ICC Article 5 does contain the word "aggression." Therefore, it might be argued, the case for exclusive determination by the Security Council is stronger with respect to the crime of aggression than with respect to an armed attack.

There are a number of problems with this philological maximalism. First, the French term for armed attack, agression armée, does appear to contain the word aggression. Second, while the term "act of aggression" in Article 39 is different from the term "armed attack" in Article 51, the term "act of aggression" in Article 39 is also different from the term "crime of aggression" in ICC Article 5. Third, and relatedly, the term "crime of aggression" in ICC Article 5, when defined, will probably be closer in meaning to the term "armed attack," in Charter Article 51, than to the term "act of aggression" in Charter Article 39. Therefore, the ICJ's determination of armed attack is an even stronger precedent for ICC determination of the crime of aggression than might initially appear.

As previously suggested, the main difference between the "armed attack" of Article 51 and the "act of aggression" of Article 39 is that the ICJ has given the term "armed attack" a fairly definite meaning, while the Security Council has not given the term "act of aggression" anything approaching a definite meaning. ${ }^{96}$ When the term "crime of aggression" in ICC Article 5 is defined, it

94. Id. at 9139.

95. "Article 51 of the Charter thus recognizes the existence of an inherent right of selfdefence in the case of armed attack by one State against another State. However, Israel does not claim that the attacks against it are imputable to a foreign State." Id.

96. As outlined above, any inconsistency the ICJ may have displayed in applying the term "armed attack" is nothing compared to the vast inconsistency the Security Council has displayed in applying the term "aggression." 
will probably have a fairly definite meaning, like "armed attack" and unlike "act of aggression." Moreover, the definition of "crime of aggression" will probably align that term with the term "armed attack," as interpreted by the ICJ. There will probably be a gravity threshold for the crime of aggression, just as there is, the ICJ has stressed, an important gravity threshold for an armed attack under Charter Article 51. By contrast, in the practice of the Security Council, and especially its resolutions on the Israeli raids on Tunisia, ${ }^{97}$ it is hard to discern a gravity threshold for an act of aggression under Article 39 . The term "crime of aggression" may also be defined so as to require that aggression be committed by a state. It appears, based on the ICJ's 2004 advisory opinion on the Israeli wall, that the ICJ may now believe that an armed attack, under Article 51, can only be committed by a state. In Security Council practice regarding acts of aggression, however, it is hard to discern a requirement of state responsibility, given Resolution 405 regarding the mercenary attack on Benin. ${ }^{98}$ Thus, it is quite likely that when the term "crime of aggression" is defined, that term will be closer in meaning to the term "armed attack," as interpreted more or less consistently by the ICJ, than to the meaning of the term "act of aggression," as interpreted sporadically by the Security Council. ${ }^{99}$

\section{E. Alternatives to Total Exclusivity}

As previously argued, there are many reasons to reject the view that the Security Council's Article 39 power to determine the existence of aggression means that no other body can ever determine the existence of aggression. I have dealt at length with the ICJ's practice, seeking to demonstrate that the ICJ has determined the existence of aggression, in the relevant sense. I emphasize, however, that my main arguments are not based on the decisions of the ICJ; my main arguments, outlined above, are based on the Charter itself.

It will be conceded, I hope, that the Security Council cannot possibly be the sole determiner of aggression in every context in which aggression is determined. Once the position of total exclusivity is rejected, for the reasons given above, two plausible interpretations of Article 39 are left. My own interpretation (which I consider the more plausible) is that Article 39 only disables bodies other than the Security Council from determining aggression when they purport to determine it for the Security Council, thus triggering the Security Council's power and responsibility to suppress aggression under Chapter VII. I will refer to this position as Chapter VII enforcementexclusivity. An alternative interpretation is that bodies other than the Security

97. Supra Part II(B).

98. Supra Part II(B).

99. Suppose the philological maximalist persists, claiming that the meaning of terms is not important; only the use of the word "aggression" matters. If this is really the problem, perhaps the ICC Statute should be amended to remove jurisdiction over the crime of aggression and to provide instead jurisdiction over the crime of "shmaggression." 
Council are barred from determining aggression, in any context, when the Security Council has in some way asserted its Chapter VII powers, making a determination under Article 39 that there exists a threat to the peace, a breach of the peace, or an act of aggression. I will refer to this position as Chapter VII case-exclusivity.

As previously noted, the Security Council's power to determine aggression is tied to the Security Council's power to suppress aggression. Once the Security Council makes an Article 39 determination, it must do something to maintain or restore peace and security ("... and shall make recommendations, or decide what measures shall be taken....") ${ }^{100}$ The most natural interpretation of Article 39 is that the negative implication of its Determination Clause is also tied to the Security Council's power to suppress aggression: No one but the Security Council may trigger that power.

The drafting history of the Charter shows that this is not an empty interpretation. At the founding conference of the United Nations, there were some unsuccessful attempts to limit the discretion of the Security Council to determine aggression. Schuster and others see this drafting history as bolstering the total-exclusivity interpretation of Article 39. ${ }^{101}$ However, the failed proposals to limit the discretion of the Security Council were proposals to define aggression for the Security Council, so as to trigger the Security Council's enforcement responsibility. The existence of these proposals, and their ultimate failure, tell in favor of the interpretation of Article 39 that I advocate, i.e., Chapter VII enforcement-exclusivity. The report of the committee charged with drafting what became Article 39 states:

Various amendments proposed on [the determination of aggression] recalled the definitions written into a number of treaties concluded before this war but did not claim to specify all cases of aggression. They proposed a list of eventualities in which intervention by the Council would be automatic. At the same time they would have left to the Council the power to determine the other cases in which it should likewise intervene.

Although this proposition evoked considerable support, it nevertheless became clear to a majority of the Committee that a preliminary definition of aggression went beyond the possibilities of this Conference and the purpose of the Charter. The progress of the technique of modern warfare renders very difficult the definition of all cases of aggression. It may be noted that, the list of such cases being necessarily incomplete,

100. U.N. CHARTER, art. 39 (emphasis added).

101. Schuster, supra note 4, at 36. 
the Council would have a tendency to consider of less importance the acts not mentioned therein; these omissions would encourage the aggressor to distort the definition or might delay action by the Council. Furthermore, in the other cases listed, automatic action by the Council might bring about a premature application of enforcement measures.

The Committee therefore decided to adhere to the text drawn up at Dumbarton Oaks and to leave to the Council the entire decision as to what constitutes a threat to the peace, a breach of the peace, or an act of aggression. ${ }^{102}$

The phrase "The Security Council shall determine" should be read in the context of this history. ${ }^{103}$ That phrase represents a rejection of "eventualities in which intervention by the Council would be automatic."104 As a determination of aggression by the ICC would in no way purport to trigger the enforcement powers of the Security Council, such an independent determination is not barred by Article 39 .

Let us consider the other plausible interpretation of Article 39: that it establishes a regime of Chapter VII case-exclusivity, barring other bodies from determining aggression, in any context, when the Security Council has made an Article 39 determination. ${ }^{105}$ This interpretation of Article 39 is less natural than the enforcement-exclusivity interpretation I favor. Moreover, the plausibility of the case-exclusivity interpretation is weakened by ICJ decisions on an analogous issue, by the permissibility of collective self-defense under Charter Article 51, and by the Security Council's power to halt ICC proceedings under ICC Article 16.

The ICJ has often encountered arguments that it should not hear the merits of a case because the case is within the exclusive competence of the Security Council. So far, the ICJ has rejected every such argument. In Nicaragua, the Court responded to an American argument of exclusive Security Council competence by stating: "The Council has functions of a political nature assigned to it, whereas the Court exercises purely judicial functions. Both organs can therefore perform their separate but complementary functions with

102. Doc. 881, June 10, Report of Rapporteur of Committee III/3 to Commission III on Chapter VIII, Section B, in THE UNITED NATIONS CONFERENCE ON INTERNATIONAL ORganization, SElected DocumenTs 763 (1946) (emphasis added).

103. That phrase, of course, predated the attempts to change it, but the idea that aggression should be defined in advance had been in the air since the days of the League of Nations.

104. Doc. 881, supra note 102, at 763 .

105. The ILC Draft Statute would have established a regime of Chapter VII caseexclusivity as to all crimes covered by the Statute. 
respect to the same events. ${ }^{106}$ The ICJ repeated this statement in the Genocide Convention case brought by Bosnia against Yugoslavia, ${ }^{107}$ and repeated it yet again in the Armed Activities case brought by the Democratic Republic of the Congo against Uganda. ${ }^{108}$

The argument for exclusive Security Council competence in Nicaragua was not at all compelling. The Security Council had not made any Article 39 determination in that case; it had not found a threat to the peace, a breach of the peace, or an act of aggression. If there is a category of Chapter VII cases within the exclusive competence of the Security Council, the Security Council must presumably decide for itself when a case falls in that category, by making an Article 39 determination.

The ICJ left open, in Nicaragua, the possibility that it might be barred from proceeding with a case if the Security Council had in fact made an Article 39 determination as to that case. ${ }^{109}$ However, in Genocide Convention and Armed Activities (Congo v. Uganda), the ICJ rejected Chapter VII caseexclusivity argument, and granted provisional remedies, where the Security Council had made Article 39 determinations. Both of these cases involved ongoing armed conflict.

106. Military and Paramilitary Activities in and Against Nicaragua (Nicar. v. U.S.), Jurisdiction, 1984 I.C.J. 392, 995 (June 17, 1984).

107. Application of the Convention on the Prevention and Punishment of the Crime of Genocide (Bos. \& Herz. v. Yugo.), Provisional Measures, 1993 I.C.J. 3, 133 (April 8, 1993) [hereinafter Genocide Convention].

108. Case Concerning Armed Activities on the Territory of the Congo (Congo v. Uganda), Provisional Measures, 2000 I.C.J. 111, I 36 (April 11, 2000) [hereinafter Armed Activities].

109. Nicaragua, Jurisdiction, 1984 I.C.J. 392, 994.

The United States argument is also founded on a construction, which the Court is unable to share, of Nicaragua's complaint about the United States use, or threat of the use, of force against its territorial integrity and national independence, in breach of Article 2, paragraph 4, of the United Nations Charter. The United States argues that Nicaragua has thereby invoked a charge of aggression and armed conflict envisaged in Article 39 of the United Nations Charter, which can only be dealt with by the Security Council in accordance with the provisions of Chapter VII of the Charter, and not in accordance with the provisions of Chapter VI. This presentation of the matter by the United States treats the present dispute between Nicaragua and itself as a case of armed conflict which must be dealt with only by the Security Council and not by the Court which, under Article 2, paragraph 4, and Chapter VI of the Charter, deals with pacific settlement of all disputes between member States of the United Nations. But, if so, it has to be noted that, while the matter has been discussed in the Security Council, no notification has been given to it in accordance with Chapter VII of the Charter, so that the issue could be tabled for full discussion before a decision were taken for the necessary enforcement measures to be authorized. It is clear that the complaint of Nicaragua is not about an ongoing armed conflict between it and the United States, but one requiring, and indeed demanding, the peaceful settlement of disputes between the two States. Hence, it is properly brought before the principal judicial organ of the Organization for peaceful settlement.

Id. As Gray has observed, this is an obscure passage. CHRISTINE GRAY, INTERNATIONAL LAW AND THE USE OF FORCE 11 (2000). 
In Armed Activities, the ICJ's provisional remedy was not particularly daring. The ICJ basically ordered both parties to comply with a Security Council resolution. ${ }^{110}$ In Genocide Convention, the ICJ departed farther from commands that the Security Council had already laid down. It entered provisional relief against Yugoslavia that included the instruction: "The Government of the Federal Republic of Yugoslavia (Serbia and Montenegro) should in particular ensure that any ... armed units which may be directed or supported by it, as well as any organizations and persons which may be subject to its control, direction or influence, do not commit any acts of genocide." 11 The Russian judge on the ICJ voted against this portion of the Court's order on the ground that it was "open to the interpretation that the Court believes that [Yugoslavia] is indeed involved in such genocidal acts, or at least that it may very well be so involved."112

Also relevant to the notion of Chapter VII case-exclusivity are the Lockerbie cases. In these cases, Libya ultimately sought relief from Security Council resolutions, passed under Chapter VII, that required Libya to turn over suspects in the Lockerbie bombing. ${ }^{113}$ The cases were settled before judgment on the merits, and it seems likely the Security Council resolutions would have proved dispositive in the end. However, the ICJ did let the cases proceed past preliminary objections, rejecting arguments for dismissal that centered on the Security Council resolutions. ${ }^{114}$

In short, the ICJ has rejected a regime of Chapter VII case-exclusivity as far as its own proceedings are concerned. Is the argument for Chapter VII caseexclusivity any better, or any worse, regarding ICC prosecutions for the crime of aggression?

In some ways, the argument for Chapter VII case-exclusivity is better in the ICC context than in the ICJ context. The ICJ arguably has an obligation to decide cases that are properly before it, even if those cases overlap with matters under consideration by the Security Council under Chapter VII. As the ICC's jurisdiction over aggression has not yet been delimited, it is still possible to avoid such overlap between the ICC and the Security Council. Also, the ICJ, as

110. Both Parties must ... refrain from any action ... which might prejudice the rights of the other Party . . . Both Parties must . . take all measures to comply with all of their obligations under international law . . . and with United Nations Security Council resolution 1304 (2000) . . . Both Parties must ... ensure full respect .. . for fundamental human rights and for the applicable provisions of humanitarian law. Armed Activities, supra note 108, ๆ 47.

111. Genocide Convention, supra note 107, \ 52.

112. Id. (Tarassov, J., dissenting).

113. For an explanation of the complicated proceedings, see Pieter H.F. Bekker, International Court of Justice Upholds its Jurisdiction in Lockerbie Cases, ASIL INSIGHTS (Mar. 1998).

114. Questions of Interpretation and Application of the 1971 Montreal Convention Arising from the Aerial Incident at Lockerbie (Libya v. U.K.), 1998 I.C.J. 9 (Feb. 27, 1998); Questions of Interpretation and Application of the 1971 Montreal Convention Arising from the Aerial Incident at Lockerbie (Libya v. U.S.), 1998 I.C.J. 115 (Feb. 27, 1998). 
the "principal judicial organ" of the United Nations, ${ }^{115}$ may be coequal in status with the Security Council; the ICC, not being an organ of the United Nations, is inferior in status to the Security Council and the ICJ.

But there is also an important way in which the argument for Chapter VII case-exclusivity is less convincing in the ICC context than in the ICJ context. Under Article 16 of the ICC Statute, the Security Council has the power to stop all ICC proceedings in a Chapter VII case. By contrast, no Charter provision expressly gives the Security Council power to halt ICJ proceedings, and it is unclear whether the Security Council possesses such a power. An ICJ case concerning a matter under consideration by the Security Council could theoretically hamper or frustrate the Security Council in the exercise of its Chapter VII powers. In the ICC context, the Security Council can prevent any such result by suspending ICC proceedings under ICC Article 16 . To my mind, the ability of the Security Council to suspend all ICC proceedings is the key consideration in concluding that the U.N. Charter does not bar the ICC from prosecuting the crime of aggression, even in a Chapter VII case.

It is in this connection that the right of individual and, especially, collective self-defense is most telling. Under Chapter VII, the Security Council has the role of suppressing aggression. Nevertheless, Article 51 permits a group of states, acting without the prior approval of the Security Council, to cooperate in identifying and suppressing aggression. The ability of states to make war on an aggressor, pending a decision of the Security Council, is far closer to the Security Council's core Chapter VII role than is an ICC prosecution for the crime of aggression. If states are able to suppress aggression, pending a contrary decision of the Security Council, it is hard to see how it could be inconsistent with the Charter for the ICC to prosecute aggression, pending a contrary decision of the Security Council.

To be sure, the procedural parallel between collective self-defense and an ICC case is not exact. Article 51 does not say that there is a right of selfdefense until the Security Council explicitly extinguishes that right; Article 51 says that the Charter does not impair the right of self-defense "until the Security Council has taken measures necessary to maintain international peace and security." under Chapter VII, that action automatically extinguishes the right of selfdefense, even if the Security Council does not explicitly say so, or does not order an end to further fighting. ${ }^{117}$ Whatever the validity of this position with respect to self-defense, an analogous position cannot be accepted in the context of ICC prosecutions for the crime of aggression. If we are to reject Chapter VII case-exclusivity, ICC proceedings on the crime of aggression cannot be halted by a Chapter VII decision unless that decision explicitly orders a halt to ICC

115. U.N. Charter, art. 92.

116. U.N. Charter art. 51.

117. Albrecht Randelzhofer, Article 51, in THE ChARTER OF THE UNTTEd NATIONS: A COMMENTARY 804 (Bruno Simma et al., eds.) (2d ed. 2002). 
proceedings. Nevertheless, the basic principle would be the same: Action against aggression is permitted, subject to the authority of the Security Council. And while the procedural authority of the Security Council over ICC proceedings is somewhat less, under ICC Article 16, than the procedural authority of the Security Council over international conflicts under Article 51, the Security Council's substantive need to stop a legal proceeding is presumably not as great as the Security Council's substantive need to stop a war.

\section{PROPOSALS}

The Charter does not make the Security Council the exclusive determiner of aggression in a prosecution for the crime of aggression. As argued in Part II, exclusive determination would actually be in tension with a number of important Charter-based principles, including the sovereign equality of states, the nature of the Security Council as a political rather than a judicial body, and the exclusive authority of the Security Council to determine aggression in the context of its own decisions.

Those who believe the Charter requires exclusive determination read into Article 39 a broad negative implication - no body other than the Security Council may determine aggression in any context - that simply is not there. The true negative implication of Article 39 is that no body other than the Security Council may determine aggression for the Security Council, triggering the Security Council's responsibility and power to suppress aggression. As no scheme for the determination of aggression in ICC proceedings purports to trigger the Security Council's responsibility and power to suppress aggression, no such scheme violates Article 39. Ironically, exclusive determination schemes are the least consistent with Article 39, as they push the Security Council into applying the definition of aggression in the ICC Statute.

\section{A. Increasing the Security Council's Power}

A non-exclusive procedure for the determination of aggression in ICC proceedings is fully consistent with the Charter. However, to achieve maximum alignment between the ICC Statute and the Charter, the Security Council should be given additional powers in proceedings concerning the crime of aggression, beyond the powers it already possesses, under ICC Article 16, to suspend proceedings involving war crimes, crimes against humanity, and genocide. In prosecutions for the crime of aggression, the Security Council should be able to go beyond the one-year renewable suspension provided for in ICC Article 16; the Security Council should be able to call a permanent halt to ICC proceedings on the crime of aggression. Moreover, the Security Council should be able to undo ICC prosecutions for the crime of aggression. It should be able to vacate charges and even expunge convictions. These changes would make it clear that in matters concerning the crime of aggression, the ICC will be 
completely subordinate to the Security Council as a body, though the ICC will not be subordinate to the veto of any one permanent member.

The aggression procedures should also guard against ICC decisions that are inconsistent with decisions of the Security Council or the ICJ. There are two perspectives from which an ICC decision might be judged inconsistent with a decision of the Security Council. One is the perspective of the Security Council itself. Preventing decisions that are inconsistent from the Security Council's own perspective is not a major problem, given ICC Article 16: The Security Council can itself prevent such decisions. The second perspective on how an ICC decision could be inconsistent with a decision of the Security Council is a more objective, juridical perspective. Suppose that the Security Council brands one state in a conflict as a wrongdoer (a threat to the peace, breacher of the peace, or aggressor). The ICC then investigates and prosecutes a leader of the opposing state for the crime of aggression. ${ }^{118}$ It is conceivable that the Security Council could not pass a resolution to stop such ICC proceedings, for example, because of a change in the political views of one of the permanent members. Nevertheless, the prosecution should not go forward. And of course, there should be no ICC prosecution for aggression if the Security Council has made an explicit decision that the state in question did not commit aggression.

In my view, these are the only situations in which ICC proceedings would be inconsistent with a prior decision of the Security Council. It would not be inconsistent for the ICC to proceed on a case of aggression merely because the Security Council had failed to determine the existence of an act of aggression (this is, of course, another way of posing the exclusivity issue). It would not even be inconsistent for the ICC to acquit in a prosecution for the crime of aggression, where the Security Council had previously determined the existence of an act of aggression by the state in question. A determination by the Security Council that a state has committed aggression must have some preclusive effect. However, it should still be possible for the ICC to acquit the leaders of that state, if, for example, the gravity threshold in the ICC Statute has not been met. $^{119}$

\section{B. Bringing in the ICJ}

The risk of inconsistent decisions is actually greater with respect to the ICJ than with respect to the Security Council. By the time the ICC proceeds to a verdict on a prosecution for the crime of aggression, it is likely that the

118. "[I]n theory at least ... the ICC (if acting independently of the Security Council) might convict a person of the crime of aggression, even though the Council has ruled that the other side is the aggressor in the war." YORAM DINSTEIN, WAR, AGGRESSION AND SELF-DEFENCE 111-112 (3d. ed. 2001).

119. For an illuminating discussion of possible divergences between a Security Council decision and a judgment of the ICC, see Clark, supra note 7. 
Security Council will already have made every decision that could possibly conflict with the ICC's own decision. Therefore, it should be fairly easy to avoid inconsistency between decisions of the ICC and the Security Council.

The ICJ, however, often works more slowly than the Security Council. The ICJ could be in the early stages of a case alleging unlawful use of force at the same time the ICC is in the early stages of investigating an alleged crime of aggression. The ICJ is also more likely than the Security Council to decide that a given party either is or is not at fault in a conflict.

Avoiding conflict with a decision of the ICJ is one very good reason to seek an ICJ advisory opinion in ICC aggression cases. Another good reason is the widespread perception that the ICC needs the imprimatur of a principal organ of the United Nations in such cases. The ICJ is the logical choice, as it is a judicial body and has several times made determinations concerning the unlawful use of force.

A procedure requiring an opinion of the ICJ has none of the defects of a procedure requiring a decision of the Security Council. The ICJ precondition would not erode sovereign equality, would not entrust judicial issues to a political body, and would not push the Security Council into using a definition of aggression, for its own decisions, that has been devised by some other body.

Some proposals have it that if the Security Council does not make a determination in a limited period of time, the ICC will request that the General Assembly seek an advisory opinion from the ICJ. ${ }^{120}$ But for the reasons given previously, it is best to avoid presenting to the Security Council, even on a temporary basis, legal issues involved in an ICC prosecution for aggression. In an appropriate case, the ICC should simply ask the General Assembly to seek an advisory opinion from the ICJ.

There are, however, potential problems with a scheme requiring ICJ participation. What if the General Assembly refuses to request an advisory opinion from the ICJ? The decision to request an ICJ advisory opinion is itself a political decision, one that could be blocked in the General Assembly for political reasons. Suppose that the ICC is investigating whether Israel has been the victim of aggression. The General Assembly might not cooperate in seeking an advisory opinion in such a case, or in other cases with unpopular alleged victims.

The other possible problem with an ICJ precondition is that the ICJ might theoretically refuse to give advisory opinions in ICC cases, even if such opinions are requested by the General Assembly. Given the ICJ's advisory opinion in the Wall case, it seems unlikely that the ICJ would so refuse, ${ }^{121}$ but ICJ participation cannot be considered certain.

120. Gurmendi, supra note 7 , at 603.

121. "Given its responsibilities as the 'principal judicial organ of the United Nations' ... the Court should in principle not decline to give an advisory opinion. In accordance with its consistent jurisprudence, only 'compelling reasons' should lead the Court to refuse its opinion." Wall, supra note 92, 9 44. (Citations omitted). 
In light of these possible obstacles to an ICJ advisory opinion, such an opinion should not be an absolute precondition. In all aggression cases, the ICC should request that the General Assembly seek an advisory opinion from the ICJ. But if the General Assembly refuses to seek an opinion, or the ICJ refuses to deliver it, the ICC should be able to proceed.

Assuming that the ICC is able to obtain ICJ participation, it would not be necessary to present to the ICJ the issue of whether one or another state in a conflict had committed aggression, as that term is ultimately defined in the ICC Statute. The better course might be to ask the ICJ to apply Charter-based standards to determine whether a state had used unlawful force or had made an armed attack. The ICC could then take these decisions into consideration, ensuring consistency but also reserving to itself any issues that might be specific to the ICC Statute. Even if the ICJ determines that a state has made an armed attack, within the meaning of Article 51 of the Charter, there might still be some grounds to conclude that the leaders of that state are not guilty of aggression. For example, there might be factual issues as to which the ICC would apply a more demanding standard of proof than the ICJ.

\section{Compromise with the Veto?}

The foregoing proposals would, in my view, best effectuate the purposes of the U.N. Charter and the ICC Statute. But the process of amending the ICC Statute is a political process, one that may require compromise to protect the interests of the permanent members of the Security Council. I therefore outline here a compromise on the role of the Security Council, one that would not be ideal, but would give something to both sides in the debate over the prerogatives of the permanent members. ${ }^{122}$ Under this compromise, the ICC would be able to proceed in aggression cases, without Security Council approval, but only up to the point where charges against an accused are confirmed under Article 61 of the ICC Statute. ${ }^{123}$ After confirmation of the charges, further proceedings would require approval of the Security Council, subject to veto by the permanent members.

As part of this compromise, the pretrial arrest procedures in the ICC Statute would have to be modified in aggression cases. ${ }^{124}$ Individuals accused of the crime of aggression would not be subject to arrest without Security Council approval, but the ICC would be able to proceed to confirmation of charges in the absence of the accused.

122. My discussion of this proposed political compromise is reproduced, in large part, from Mark S. Stein, The Role of the Security Council in Prosecutions for the Crime of Aggression, 1 ACCOUNTABILITY: NEWSLETTER OF THE ASIL INTERNATIONAL CRIMINAL LAW INTEREST GROUP 810 (Fall, 2002).

123. See ICC Statute, supra note 1, art. 61.

124. See ICC Statute, supra note 1, arts. 58-61. 
Why would supporters of an exclusive determination scheme accept this compromise? They might accept it because it achieves the major political objective of the permanent members of the Security Council: Those states would be able to shield officials accused of aggression from criminal liability. Why would opponents of an exclusive determination scheme accept this compromise? They might accept it because it allows an airing of the case against the accused and a preliminary determination that the charges are sufficient to warrant trial. Also, the confirmation of charges under Article 61 of the ICC Statute would place considerable political pressure on the Security Council to authorize further proceedings.

Such a political compromise over the role of the Security Council begs the question whether the Security Council's Article 39 power to determine the existence of aggression really is exclusive. In the terminology I offered earlier, there would be an exclusive referral scheme, not an exclusive determination scheme. The Security Council would not actually determine the existence of aggression; it would simply decide whether to allow cases to proceed.

But if a political compromise can be reached the legal issue may evaporate. In order to obtain their political goal of a procedure subject to veto, permanent Council members and those who support their prerogatives have pressed the legal argument for Article 39 exclusivity. It may be doubted, however, whether permanent members would truly be interested in making a determination of aggression in the context of ICC proceedings if they were offered some other way to veto a prosecution that threatened their interests.

My proposal for a political compromise is somewhat similar to one offered by Benjamin Ferencz. ${ }^{125}$ Mine, however, is a little less deferential to the permanent members of the Security Council. Ferencz would make a determination of aggression by the Security Council a precondition to prosecution for the crime of aggression, except that "[f]ailure of the Council to respond to allegations of aggression within a reasonable time shall not prevent the court from investigating the charges and publishing its findings and recommendations."

I reiterate that my proposal for a political compromise does not represent my view of how the ICC should ideally exercise its jurisdiction over the crime of aggression. Ideally, there should be an independent procedure, one in which the Security Council is not asked to determine aggression in the context of an ICC case, and in which a prosecution cannot be thwarted by the veto of a single permanent member of the Security Council.

125. Benjamin B. Ferencz, Deterring Aggression by Law - A Compromise Proposal (Jan. 11,2001 ), available at http://www.benferencz.org/defined.htm (last visited Sept. 30, 2005).

126. Id. 
D. Resolving the Exclusivity Issue

Finally, I offer a proposal as to the process of arriving at a resolution of the Security Council's role. Some believe that the Charter requires an exclusive determination scheme. Others reject this conclusion, and I have argued that exclusive determination would actually be less consistent with the Charter than independent determination. Given the importance of the issue, the obvious course would be for the ICC Assembly of States Parties to ask the General Assembly to seek an advisory opinion from the ICJ that would give guidance on which schemes are permissible under the Charter. The ICJ might be presented with several proposals and asked to decide whether each is consistent with the Charter. Alternatively, the ICJ might be presented with a simple question, for example: "Under the U.N. Charter, must the Security Council determine that there exists an act of aggression before there can be any prosecution for the crime of aggression before the International Criminal Court?"

Whatever one may think of proposals to involve the ICJ in individual aggression cases, surely there can be no principled objection to seeking an advisory opinion from the ICJ, the principal court of the United Nations, on what kinds of procedures are consistent or inconsistent with the Charter. There may be some political reluctance on both sides to seek such an advisory opinion, because of uncertainty over how the opinion will come out. But if the ICJ is going to have doubts about the Charter-legality of a scheme for the ICC's exercise of jurisdiction over the crime of aggression, it is best to discover such doubts before the scheme is written into the ICC Statute. 